\title{
The Equity Premium and the Government Cost of Capital: A Response to Neville Hathaway
}

\author{
John Quiggin
}

$\mathbf{P}$

RIVATISATION has become an important trend in public policy since the 1980 s. The impact of privatisation on public sector net worth may be assessed by comparing the sale price of an enterprise with estimates of the present value of its future net profits under continued public ownership discounted at the bond rate: the so-called 'present value approach'. Under the assumption that earnings are expected to remain constant in real terms, the present value approach is equivalent to a simple comparison between the expected net profits forgone through privatisation, including nominal capital gains, and the annual savings in interest payments arising when privatisation proceeds are used to repay public debt. ${ }^{1}$

The privatisations of enterprises including British Telecom, the Commonwealth Bank and the Commonwealth Serum Laboratories, the New South Wales Government Insurance Office and the proposed partial privatisation of Telstra have been analysed using the present value approach (Brown, 1996; Casey \& Dollery, 1996; Hamilton \& Quiggin, 1995; Quiggin, 1995, 1996). In all but one of these cases (that of the NSW Government Insurance Office, analysed by Casey and Dollery), the sale price was found to be less than the present value of future earnings, or equivalently the interest saved annually by using the proceeds of privatisation to repay debt was less than the expected annual net profits forgone through privatisation.

Of the reasons why sale prices fall short of the present value of future earnings discounted at the bond rate, the most important is the 'equity premium', that is, the fact that the real interest rate for both government bonds and good-quality private bonds is less than the average real rate of return demanded by holders of private equity (Mehra \& Prescott, 1985). ${ }^{2}$ It follows that the market value of a private firm will be less than the expected value of its future earnings, discounted at the real

\footnotetext{
1 The analysis may also be undertaken in real terms, focusing on the real component of interest savings and disregarding nominal capital gains. These adjustments wash out, leaving the results unchanged.

${ }^{2}$ Mehra and Prescott's analysis is based on evidence from stock markets, and therefore applies directly to estimates of the sale value of an enterprise which is sold by public float. In some cases, a trade sale may yield higher returns. This corresponds to the frequent observation that a takeover bid for a private firm may incorporate a control premium.
} 
bond rate. Moreover, the cost of capital to the private sector, which is equal to a weighted average of the bond rate and the rate of return to private equity, is greater than the cost of capital to the public sector, which is equal to the bond rate.

The sale price that can be realised for a government enterprise under privatisation will differ from the present value of its expected net profits under public ownership, in two main ways. If the stream of net profits is expected to be higher under private ownership than under public ownership, this will raise the sale price. On the other hand, the fact that holders of private equity demand higher rates of return than holders of public debt, so that the cost of capital to private firms is higher than the cost of capital to the government, will reduce the sale price: a point first made by Walker (1994).

The present value approach takes both of these effects into account. If the expected increase in net profits arising from the shift from public to private ownership is sufficiently great to offset the higher cost of capital to the private sector, the sale price will exceed the present value of net profits under continued public ownership, and privatisation will be found to increase public sector net worth. More precisely, privatisation will increase public sector net worth if and only if the ratio of expected profits under private ownership to expected profits under public ownership is greater than the ratio of the private sector cost of capital to the public sector cost of capital.

In his recent article in Agenda, Neville Hathaway (1997) criticises the present value approach, arguing that the true cost of capital to government is at least as great as the average cost of capital to private sector firms. He begins by claiming that the present value approach would imply the desirability of public ownership of all business enterprises, a claim which will be referred to as the 'comprehensive socialisation argument'. He then discusses the appropriate treatment of company tax. Finally, Hathaway considers the indirect costs of public ownership of business enterprises, that is, the risk borne by taxpayers as a result of the riskiness of the income flow from government business enterprises. Hathaway draws on Bailey and Jensen's (1972) critique of the Arrow-Lind (1970) proposition that no risk premium should be charged for public investments. A related argument is presented by Fred Gruen (1997).

In this article, it is argued that Hathaway's comprehensive socialisation argument is fallacious, and that the issue of differential tax treatment is peripheral to the argument. The only issues of substance relate to the assessment of the indirect cost of public ownership. Analysis of the 'equity premium puzzle' (Mehra \& Prescott, $1985)$ is used to show that the arguments of Bailey and Jensen (1972) depend crucially on the invalid assumption of perfect and costless capital markets. It is argued that the cost of capital to government will in general be somewhat above the real bond rate, but below the average cost of capital to private firms. 


\section{The Comprehensive Socialisation Argument}

The reductio ad absurdum (showing that your opponent's conclusion leads to an absurd implication) is always a dangerous form of argument, particularly when the user fails to take account of ceteris paribus conditions. A typical misapplication of this argument might proceed as follows. A standard principle of production economics is that, other things being equal, it is desirable to minimise transport costs by locating production as close as possible to the point of consumption. This principle could be 'refuted' by the observation that the absolute minimum of transport costs would be achieved if all production was undertaken by households with no trade of any kind. Since this is clearly undesirable, it may be claimed that transport costs should be disregarded in location decisions. The fallacy here is obvious: although household production minimises transport costs, it does so at the expense of gains from trade, economies of scale, and so on. Simply put, other things are not equal.

No economist would seriously advance a reductio ad absurdum argument to prove that differences in transport costs should be disregarded in determining the location of production. However, the observation that the cost of capital to government is less than the rate of return demanded by holders of private equity seems to generate an overwhelming urge to use a formally identical reductio ad absurdum argument, such as the comprehensive socialisation argument.

Hathaway begins with the claim that, if the apparently lower cost of capital to government business enterprises were real, national welfare could be greatly increased by public ownership of all business enterprises. An identical claim is made by Domberger (1995). As with the transport cost example, the reductio ad absurdum argument would be valid only if all other things were equal, that is, if government and private enterprises were identical in all respects except for the cost of capital. Hathaway, however, argues that other things are not equal, claiming that private ownership will enhance efficiency. ${ }^{3}$ Under the present value approach, privatisation may increase public sector net worth if the profitability of private firms is greater than that of publicly owned firms, either because of greater operating efficiency or because of lower payments to employees or the abandonment of community service obligations. The extent to which increases in profitability arising from privatisation and related processes such as contracting out is due to efficiency

\footnotetext{
${ }^{3}$ Hathaway claims, not merely that government enterprises are less profitable than they would be under private ownership, but that many government enterprises are chronically unprofitable, that is, yield a negative return to capital. It is self-evident that the present value of a stream of negative returns must be negative whatever the opportunity cost of capital. Hence, if privatisation would make such enterprises profitable, implying that the sale price of the enterprise is positive, privatisation must improve the government's net worth. Cases of this kind are not common in the Australian public sector. Hathaway cites the case of the Australian National Line (ANL), analysed by Trace (1995). This enterprise is, indeed, chronically unprofitable, but plans for privatisation were abandoned because, as a government minister put it, 'you couldn't give it away' (Trace, 1995:441). This implies that, given the conditions under which ANL was required to operate, private owners could not make it profitable. Thus, the unprofitability of ANL is due to factors other than public ownership. However, consideration of cases of this kind is sufficient to demonstrate the fallacy in Hathaway's reasoning.
} 
gains rather than to transfers from employees, consumers and others has been debated by Domberger et al. (1986), Ganley and Grahl (1988) and Quiggin (1994), among others. But in assessing the impact of privatisation on the government's net worth, this issue is not relevant. The critical fact is that if privatisation is expected to increase profitability, the ceteris paribus condition implied on which Hathaway's argument relies is not satisfied.

The trade-off between the lower cost of capital for government enterprises and the effects of increased profitability arising from privatisation may be described more formally. For any enterprise, net profit - the return to equity after interest and tax - must satisfy the identity

$$
\pi E=(1-t)(Y-r g E-L)
$$

where $\pi$ is the rate of return to equity; $E$ is the value of equity; $t$ is the tax rate; $Y$ is value added; $r$ is the rate of return to debt; $g$ is the ratio of debt to equity; and $L$ is labour cost.

Hence an increase in $\pi$, the required rate of return to equity will leave the value of equity unchanged if and only if it is accompanied by a proportionate increase in net profits $Y-r g E-L$. Suppose, in particular, that the cost of capital to the government is 5 per cent while the rate of return demanded by holders of private equity is 10 per cent, and consider an enterprise where the debt-equity ratio, $g$, is equal to 1 and the labour share of initial value added is two-thirds. For simplicity, assume that $t=0$. Then net profit is initially equal to one-sixth, or 16 per cent, of value added.

Suppose now that the enterprise is privatised, doubling the required rate of return to equity, and that, simultaneously, value added is increased by 16 per cent with no corresponding increase in costs. Then net profit is also doubled and the value of equity is unchanged. That is, in this illustrative example, private buyers would be willing to pay the government an amount equal to the present value of future earnings under continued public ownership discounted at the rate of 5 per cent. Using the parameters of the example, a 20 per cent difference in total factor productivity would be more than sufficient to offset the difference between a 5 per cent and a 10 per cent cost of equity capital.

The more capital intensive the enterprise, however, the greater is the required difference in net profit. Hence, it is not surprising that profitable government business enterprises have mostly been found in capital-intensive sectors of the economy. On the other hand, if the enterprise is sufficiently labour intensive, reductions in labour costs can give rise to the situation mentioned by Hathaway, where, under public ownership, net profits $Y-r g E-L$ are negative, even though competing private firms can yield a positive net profit.

In summary, the comprehensive socialisation argument would be valid if all other things were equal, and, in particular, if the profitability of an enterprise were independent of whether the enterprise was privately or publicly owned. Since privatisation frequently increases profitability, other things are not equal, and the argument fails. 


\section{Variants of the Comprehensive Socialisation Argument}

Fred Gruen (1997) and Peter Forsyth (1997) argue that governments could undertake passive equity investments in a wide range of private enterprises and that, therefore, the opportunity cost of public equity investment is equal to the average rate of return on private equity capital. It is not clear whether this suggestion would be feasible in practice. Difficulties such as potential conflicts of interest would need to be addressed. Nevertheless, the suggestion deserves to be taken seriously and the possibility of an equity investment strategy for the Social Security Fund (which is currently permitted to hold only debt) is being debated in the United States.

Suppose for the sake of argument that passive government investments in private equity could be made. There are clearly limits to the size of the shareholdings that could be accumulated in this way while achieving the average rate of return to private equity. If government were committed to a purely passive role in enterprises in which it was a major shareholder, the management and the other shareholders would have an incentive to engage in rent-seeking at the expense of the government shareholder. This could be done, for example, by transferring wealth within a corporate structure from entities with a government shareholding to entities owned by the other shareholders. Hence, as the size of shareholdings increased, the marginal return from a purely passive strategy would decline to the point where it was equal to the government's cost of capital. Once this point was reached, the opportunity cost of capital to the government would be equal to the bond rate, adjusted for the cost of risk borne by taxpayers.

Gruen's argument would work if the amount governments could invest in passive equity holdings was so large that equilibrium would be achieved through an increase in the cost of capital to government. To derive an upper bound to the amount that could be passively invested, it is necessary to estimate, first, the maximum holding in an individual enterprise consistent with the status of a passive shareholder, and second, the total value of enterprises in which investments could be made.

A range of existing limits on shareholding suggest that an investor holding more than 15 per cent of the equity in an enterprise is not normally regarded as passive, and, as Hathaway observes, the aggregate value of all the listed stocks on the Australian stock exchange is about $\$ 400$ billion. Hence, the total amount the government could invest using a passive investment strategy would be no more than $\$ 60$ billion, considerably less than the value of existing public assets.

If governments became active investors rather than passive ones, the potential shareholding could be increased. But if governments are supposed to be active owners, Gruen's (1997) argument reduces to the comprehensive socialisation argument. If complete government ownership of existing private enterprises is likely to generate efficiency losses, the same will presumably be true for partial ownership.

In summary, while the possibility of passive public investment in private equity is worthy of discussion, the outcome of such a discussion would not affect the validity of a present value analysis of privatisation. If passive public investment is feasible, it should be undertaken up to the point where the marginal return is equal to 
the cost of capital to the public sector. On the basis of the considerations set out above, it is unlikely that the adoption of such a strategy would greatly increase the marginal cost of capital to the public sector.

\section{Company Tax, Dividends and Earnings}

Hathaway criticises the claim, attributed to unnamed opponents of privatisation, that public ownership is desirable because public enterprises are exempt from company tax. Except in relation to the distribution of income between the Commonwealth and the States, discussed by Forsyth (1994), I am not aware that anyone has suggested that public ownership is desirable because of the tax-exempt status of public enterprises. The analyses presented in Brown (1996), Hamilton and Quiggin (1995), and Quiggin $(1995,1996)$ are based on evaluations of streams of posttax profits and include adjustments to take account of cases of preferential tax treatment for public enterprises. There are, as Hathaway observes, practical difficulties in determining the tax rate that should be applied, since it is necessary to take account of the interaction of company income tax, personal income tax, dividend imputation and the scope for various forms of tax minimisation. I would welcome a serious effort to improve the present value estimates through the use of more accurate estimates of imputed tax rates. Similarly, it is important in evaluating the returns from privatisation to take account of the tax subsidies that have been associated with most recent privatisation and private infrastructure projects.

A more relevant point regarding company tax, and, more generally, the taxation of capital income, is that such taxes tend to reduce the level of private saving. If taxes on capital income are deemed necessary on distributional grounds, and if domestic investment is determined by domestic savings, as argued by Feldstein and Horioka (1980), there is a second-best case for the public sector to undertake savings and investment, thereby increasing the aggregate level of domestic investment. The relevant riskless opportunity cost for public investment will be a weighted average of the return to riskless private investment and the discount rate applicable to private consumption, with the weights determined by the proportion to which public investment crowds out private investment (see Marglin, 1963). However, recent analyses of privatisation using the present value approach have not relied on arguments of this kind.

A further issue, on which Hathaway's position is unclear, is the treatment of retained earnings in present value analyses of privatisation. A number of studies of privatisation have been flawed by the error of examining the forgone flow of dividends to the Budget sector rather than the forgone flow of earnings, an approach which is inconsistent with the Modigliani-Miller (1958) theorem on the irrelevance of dividend policy and capital structure. In particular, Modigliani and Miller refute the claim that earnings not paid out as dividends are 'locked up', pointing out that shareholders can duplicate the effects of any dividend policy by selling shares and thereby realising the capital gains associated with retained earnings.

Studies that examine dividends include only Coughlin's (1987) case for privatisation of the Commonwealth Bank and Telstra's submission on its own privatisa- 
tion, which states: 'The government exchanges the expected value of future dividends for the sale price' (Telstra, 1996:19). The irrelevance of dividend policy may be seen more directly from the fact that the government can set the dividends of a public enterprise at any level it chooses, including a level in excess of earnings. The special dividend of $\$ 3$ billion recently announced for Telstra is an illustration of this point.

\section{The Indirect Cost of Public Ownership}

The substantial issue addressed by Hathaway is that of the indirect cost of public ownership: that is, the risk borne by taxpayers as a result of the riskiness of the income flow from government business enterprises. Hathaway's arguments are equivalent to the claim that, even though the earnings that are forgone through privatisation are less, on average, than the interest saved when the sale price is used to repay debt, taxpayers are better off because they are no longer exposed to the risk associated with ownership of the enterprise. The pure risk borne indirectly by taxpayers by virtue of public ownership of equity in government business enterprises should be taken into account in the analysis of privatisation. However, Hathaway's discussion of the issue contains a number of errors.

One problem is a failure to distinguish between an appropriate actuarial allowance for the risk of losses and the subjective premium associated with unpredictable fluctuations in returns about a given mean value. Hathaway focuses on the former concept. However, the present value approach involves discounting the expected value of future returns, and the possibility of losses is taken into account in the computation of expected future returns. That is, the estimate of future returns used in the present value approach is based on consideration, not only of the most likely future outcome, but also of the possibility that earnings will be less than or greater than the anticipated value. ${ }^{4}$ The relative insignificance of the actuarial allowance for the cost of government guarantees may be seen from the fact that the rate of return to high-quality private debt is very similar to the government bond rate.

The critical issue is the comparison between the pure risk premium associated with holdings of private equity and the cost of the pure risk borne indirectly by taxpayers by virtue of public ownership of equity in government business enterprises. The present value analysis of privatisation rests on the assumption that the indirect cost of public ownership is approximately equal to the expected cost, namely, the real bond rate (more precisely, the bond rate adjusted for the expected cost of government guarantees against default). This assumption is equivalent to a claim that the pure risk premium associated with public ownership of business enterprises is small. Hathaway's argument would be valid if it could be shown that the indirect pure risk cost of public ownership was at least as great as the pure risk premium associated with direct holdings of private equity

\footnotetext{
${ }^{4}$ Conversely, the returns from privatisation must be reduced to take account of the expected value of payments arising from guarantees provided by government to the owners of the privatised firms. Such guarantees have been a standard feature of recent privatisations and private infrastructure deals.
} 
One argument to this effect is that of Bailey and Jensen (1972), who observe that if capital markets are perfect, the allocation of risk they generate will be Paretooptimal, and so cannot be improved on by governments. Bailey and Jensen, on whose arguments Hathaway relies, assert that this is the case, saying, in Hathaway's paraphrase:

The argument that governments have access to opportunities for risk diversification that are unavailable to private investors suggests that there is some impediment in risk diversification in the private sector. But there is no logical reason why this is the case, nor is there any evidence that it is. (Hathaway, 1997:158; emphasis added)

It is perhaps not surprising that Bailey and Jensen should make such a claim in 1972. But it is surprising to see it repeated uncritically in 1997. In 1972, there had been little theoretical or empirical analysis of the impediments to risk diversification in the private sector. In particular, the theory of principal-agent relationships involving problems of adverse selection had not been developed, though the seminal paper of Akerlof (1970) had been published. The core of the adverse selection problem is that, where individuals have private information about their risk status, any private sector insurance contract will attract more bad risks than good risks. Akerlof (1970) and subsequent writers show that markets for risk diversification may not exist if adverse selection problems are present. Even where adverse selection problems can be overcome, the cost of monitoring contracts generates transactions costs which invalidate the assumptions of the perfect capital market model.

The main empirical fact of which Bailey and Jensen were unaware is the existence of a large and unexplained difference between the rate of return to debt and the rate of return demanded by holders of private equity, referred to as the 'equity premium'. The perfect capital market model predicts a very small equity premium. The basic logic is that, if the relatively small variation in aggregate consumption associated with recessions were spread evenly over the entire population, the associated risk premium would be very small. A more formal version of the argument is given by Mehra and Prescott (1985).

This analysis is formally similar to the argument of Arrow and Lind (1970), which Bailey and Jensen (1972) attempted to refute, that only a small premium should be charged for risk spread across the entire community through the tax system. However, the 'refutation' offered by Bailey and Jensen relies on the incorrect prediction that the private equity premium must be small, and the resulting incorrect implication that the premium associated with risk spread through the tax system must be at least as large as the private equity premium.

Although the equity premium remains a puzzle, the most promising explanations rest on a combination of two violations of the perfect capital market assumption. The fact that, because of adverse selection and moral hazard problems, individuals cannot insure themselves against recessions explains the premium demanded by investors for holding equity with associated systematic risk (Mankiw, 
1986). Meanwhile, the fact that the borrowing rate facing individuals is substantially higher than the bond rate invalidates the suggestion of Kotcherlakota (1996) that 'home-made' consumption smoothing will eliminate the excess risk premium.

Governments can overcome adverse selection problems through the power to impose taxes and they can borrow or lend large amounts without significant transactions costs. Hence, to the extent that the equity premium arises from these sources, the indirect cost of holding risk through public ownership will be lower than the risk premium associated with direct private ownership. On the other hand, governments have no particular advantage in dealing with moral hazard problems. It follows that public ownership permits partial correction of the market failures that generate the equity premium and that the cost of capital to the public sector lies between the government bond rate and the cost of capital to the private sector.

In his discussion, of this issue, Hathaway (1997:158-9) states:

But which should we believe: the evidence of the observed risk premium from capital markets, or a model based on a theory that claims the risk premiums are too high. The 'puzzle' does not invalidate the observed market risk premium; rather, the observed market risk premium proves that the model is flawed.

However, empirical facts, such as the existence of the observed market risk premium, cannot be 'invalidated'. The 'flawed' model to which Hathaway refers is the standard model of a perfect capital market, on which his argument, and that of Bailey and Jensen (1972), relies. Hathaway seems to be saying that simply because the observed risk premium is generated by a market, it must be 'right' in some undefined sense. With such a simple solution at hand, it is surprising that so many economists have devoted so much attention to the equity premium puzzle, and to the many other economic problems that could be resolved by the assumption that 'the market is always right'.

Because the equity premium exceeds that which would arise from a perfect capital market, the claim that the indirect cost of public ownership must be greater than or equal to the rate of return demanded by holders of private equity cannot be sustained. It is necessary to estimate the cost directly. A simple version of this calculation, based on the assumption that the risk associated with indirect holdings in public enterprises is uncorrelated with the risk associated with private consumption, yields the result obtained by Arrow and Lind, namely, that the indirect cost is approximately equal to the real bond rate.

A more appropriate calculation would take account of undiversifiable risks faced by individuals and of the way in which the tax-expenditure system allocates the risk associated with the returns to publicly owned assets. The above discussion suggests that the resulting indirect cost will lie somewhere between the real bond rate and the rate of return to private equity. I am currently undertaking research aimed at deriving more precise estimates. At this stage it seems likely that the indi- 
rect cost of capital to the public sector is closer to the real bond rate than to the private cost of capital.

\section{Concluding Comments}

Critics such as Hathaway have suggested that the present value approach to the analysis of privatisation should be rejected because it appears to imply the extreme view that all enterprises should be publicly owned. In fact, it is the advocates of privatisation who are committed to an extreme view. Because the present value approach involves a trade-off between the lower capital costs of government enterprise and the generally higher profitability of private enterprises, use of this approach implies support for a mixed economy, with public ownership concentrated in areas of high capital intensity, and private ownership in areas where capital intensity is low. Other issues relating to appropriate boundaries between the public and private sectors are discussed in Quiggin (1995).

By contrast, the a priori assumption of Hathaway and other advocates of privatisation, that any cost advantages arising from public ownership are offset by unspecified indirect costs, leads to a conclusion just as extreme as that cited above, namely, that all productive enterprises should be privately owned. The fact that mixed economies have historically been more successful than any other form of economic organisation, including free market capitalism, suggests that the present value approach to the evaluation of privatisation is correct and that approaches based on a priori assumptions about the inherent superiority of either public or private enterprises should be rejected.

\section{References}

Akerlof, G. (1970), 'The Market for "Lemons": Qualitative Uncertainty and the Market Mechanism', Quarterly Journal of Economics 84: 488-500.

Arrow, K. \& R. Lind (1970), 'Uncertainty and the Evaluation of Public Investment Decisions', American Economic Review 60: 364-78.

Bailey, M. \& M. Jensen (1972), 'Risk and the Discount Rate for Public Investment', in M. Jensen (ed.), Studies in the Theory of Capital Markets, Praeger, New York.

Brown, A.. (1996), 'Should Telstra be Privatised?', School of Economics, Griffith University, Brisbane (Working Paper No. 8).

Casey, A. \& B. Dollery (1996), 'The Privatisation of GIO Australia: Success or Failure?', Australian Journal of Public Administration 55(3): 18-25.

Coughlin, P. (1987), 'The Commonwealth Banking Corporation: A Case for Privatisation', pp. 204-25 in P. Abelson (ed.), Privatisation: An Australian Perspective, Australian Professional Publications, Sydney.

Domberger, S. (1995), 'What Does Privatisation Achieve? - A Comment on Quiggin', Australian Economic Review, 2nd Quarter: 43-7.

- S. Meadowcroft \& D. Thompson (1986), 'Competitive Tendering and Eficiency: The Case of Refuse Collection', Fiscal Studies 7(4): 69-87. 
Feldstein, M. \& C. Horioka (1980), 'Domestic Saving and International Capital Flows', Economic Journal 90(358): 314-29.

Forsyth, P. (1995), The States, Microeconomic Reform and the Revenue Problem', Federalism Research Centre, Australian National University, Canberra (Discussion Paper No. 27).

- (1997), 'Great Expectations or Hard Times? Great Expectations: Microeconomic Reform and Australia by John Quiggin', Policy 13(1): 40-3.

Ganley, J.\& J. Grahl (1988), 'Competitive Tendering and Efficiency in Refuse Collection: A Critical Comment', Fiscal Studies 9(1): 80-5.

Gruen, F. (1997), 'Irrational Expectations? John Quiggin's Critique of Microcconomic Policy in Australia', Agenda 4: 197-208.

Hamilton, C. \& J. Quiggin (1995), 'The Privatisation of CSL', Australia Institute, Canberra (Discussion Paper No. 4).

Hathaway, N. (1997), 'Privatisation and the Government Cost of Capital', Agenda 4: 155-64.

Kocherlakota, N. (1996), 'The Equity Premium: It's Still a Puzzle', Journal of Economic Literature 34(1): 42-71.

Mankiw, N. (1986), 'The Equity Premium and the Concentration of Aggregate Shocks', Journal of Financial Economics 17: 211-19.

Marglin, S. (1963), 'The Opportunity Costs of Public Investment', Quarterly Joumal of Economics 77: 274-89.

Mehra, R \& E. Prescott (1985), 'The Equity Premium: A Puzzle', Journal of Monetary Economics 15(2): 145-61.

Modigliani, F. M. Miller (1958), "The Cost of Capital, Corporation Finance and the Theory of Investment', American Economic Review 68: 261-97.

Quiggin, J. (1994), 'The Fiscal Gains from Contracting Out: Transfers or Efficiency Improvements?', Australian Economic Review, 3rd Quarter: 97-102.

— (1995), 'Does Privatisation Pay ?', Australian Economic Review, 2nd Quarter: 23-42.

- (1996), 'The Partial Privatisation of Telstra: An Assessment', Submission to Senate Environment, Recreation, Communications and the Arts Reference Committee inquiry into the Telstra (Dilution of Public Ownership) Bill 1996.

Telstra (1996), Submission to Senate Environment, Recreation, Communications and the Arts Reference Committee inquiry into the Telstra (Dilution of Public Ownership) Bill 1996.

Trace, K. (1995), “You Couldn't Give It Away”: Privatising the Australian National Line', Agenda 2: 433-44.

Walker, R. (1994), 'Privatisation: A Reassessment', Joumal of Australian Political Economy 34: 27-52.

I am grateful to two referees for comments on a previous draft. 